Int. J. Morphol.,

28(1):171-174, 2010

\title{
Evaluation of the Baudoin Condylar Index Diagnostic Test for Sex Determination
}

\author{
Evaluación de la Prueba Diagnóstica Índice Condíleo de Baudoin para Determinación del Sexo
}

"Iván Suazo Galdames; **Daniela Zavando M.; ***Priscila Russo \& ${ }^{* * * *}$ Ricardo Luiz Smith

SUAZO G. I.; ZAVANDO M. D.; RUSSO P \& SMITH R. L. Evaluation of the Baudoin condylar index diagnostic test for sex determination. Int. J. Morphol., 28(1):171-174, 2010.

SUMMARY: This article analyzes the performance of diagnostic tests for sex determination by examining human skulls, using the Baudoin condylar index. For this study, 215 skulls were examined, and the maximum dimensions (length and width) of the right and left occipital condyles, were noted. With these data, we calculated the Baudoin condylar index and determined the level of agreement between the values for the left and the right side, the sensitivity of the method, the accuracy of the tests and the positive predictive value for each sex. The level of agreement in the diagnosis based on both sides was $65.58 \%$ (of which $83.09 \%$ were of women, and $63.88 \%$ were of men). The overall accuracy was $41.39 \%$, and a greater sensitivity was seen in women (52.1\% right side and $64.78 \%$ left). The positive predictive value was higher in male skulls (77.6\% right side, left side $76.68 \%)$. These results question the usefulness of the Baudoin condylar index for the diagnosis of sex and discuss the usefulness of their applicability in forensic and anthropological practice.

KEY WORDS: Sexual dimorphism; Sex determination; Occipital condyles; Baudoin Index; Condylar index.

\section{INTRODUCTION}

Sex determination tests for forensic purposes from human skulls have used a large number of quantitative morphological methods, which take into account, the linear dimensions or areas that are integrated into discriminant functions (Kalmey \& Rathbun, 1996; Kemkes \& Gobel, 2006; Suazo et al., 2008a, 2008b; Suazo et al., 2009a, 2009b), as well as other qualitative methods to observe the outward appearance of surface characteristics, their shape and relation to other elements of the skull (Rogers, 2005).

The occipital condyles are among the 16 classical morphological indicators of sexual dimorphism described by Krogman (1955) and Krogman \& Iscan (1986), the diagnostic value of systematic observation was recently studied by Suazo et al. (2009c). These authors have reported that sex determination by observation of the occipital condyles shows a good performance overall (Odds Ratio 14.1), a high accuracy (79.3\%), with greater sensitivity and predictive value for males.

From a quantitative point of view, the occipital condyles are frequently used to calculate the index and are cited in * Universidad de Talca, Chile.

** Universidad Autónoma de Chile, Chile.

*** Departamento de Morfología e Genética, Universidade Federal de São Paulo, Brasil. anatomy, forensic anthropology and forensic medical texts as a method for the determination of sex (Testut \& Latarjet, 1974; Da Silva, 1997; Vanrell, 2002; Galvão, 2008). The condylar index, also called the Baudoin condylar index, establishes a percentage relationship between the maximum length and width of the condyle, where if the result is greater than 55, the skull is considered to belong to a female, and if less than 50, is considered male, results between 50 and 55 are considered inconclusive (Baudoin, 1928). This method has been widely used, though some reports have indicated a low accuracy in specific populations (Galvão, 1994; Machado, 2000).

Against this background, the purpose of this study was to evaluate the performance of the Baudoin condylar index diagnostic test for sex determination in human skulls.

\section{MATERIAL AND METHOD}

We analyzed 215 human skulls, belonging to the collection of the Universidade Federal de São Paulo 
(UNIFESP). Using convenience sampling, skulls which met the eligibility criteria were selected. The criteria for inclusion were those skulls with complete registration of sex and age, belonging to adults (over 18 years old), which were in a state of preservation that allowed for measurement. We excluded those which had a history of trauma or evidence of dismorphosis.

The sample was composed of 144 skulls of men, between 20 and 82 years old, with a mean age of 44.3 years (SD 30.7), and 71 skulls of women between 18 and 100 years old, with a mean age of 40.76 years (16.7).

Using a digital caliper $(0.01 \mathrm{~mm})$, the length and width of the right and left occipital condyles was determined directly (Fig 1).

Using the software SPSS 15.0, statistical descriptors were calculated from the measurements, the averages for each sex were analyzed by $\mathrm{t}$ test, and those with $\mathrm{p}<0.05$ were considered significant.

The diagnostic value of the Baudoin index was analyzed to determine the level of agreement in diagnosis between the left side and right side, the accuracy of the method, sensitivity, and the positive predictive value for each sex.

\section{RESULTS}

All the dimensions of the occipital condyles were higher in the skulls of men; a detailed summary of the statistics is in Table I.

In statistical analysis by gender, only the differences in maximum length were statistically significant.

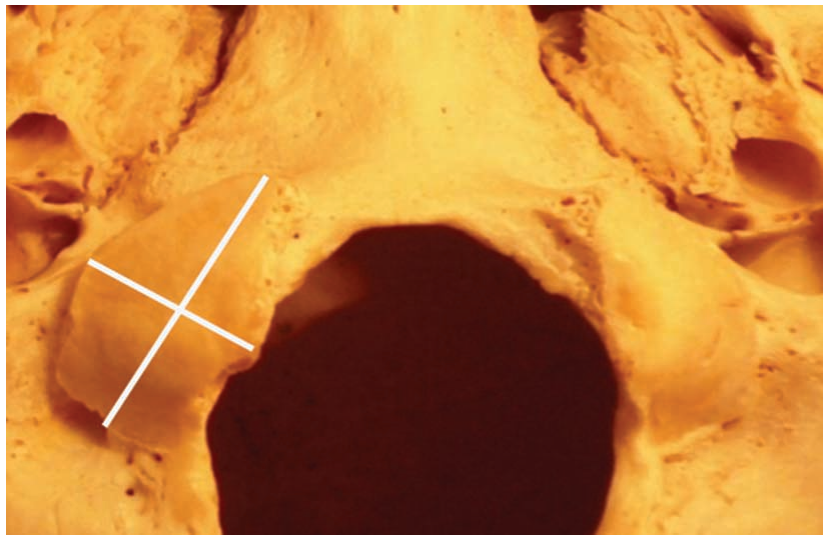

Table I. Descriptive statistics of the maximum dimensions of the occipital condyles in 215 skulls from UNIFESP, Brasil collection.

When calculating the Baudoin index, the level of general agreement in the diagnosis of sex, based on differences between the left and right sides was $65.58 \%$, this percentage was higher in the skulls of women at $83.09 \%$, while the percentage of agreement in male skulls was $63.88 \%$. Then, considering only the skulls, the level of general agreement in the diagnosis of sex between the left and right sides was $30.69 \%$, this percentage was higher in the skulls of women at $47.88 \%$, while in the skulls of men, the percentage of agreement was $22.22 \%$.

The overall accuracy rate for diagnosing sex based on the Baudoin index was $41.39 \%$ for both sides, the sensitivity for males was $36.1 \%$ on the right side and $29.86 \%$ on the left side; and for women, the sensitivity was $52.1 \%$ on the right side and $64.78 \%$ on the left side. The positive predictive value for men was $77.6 \%$ on the right side and $76.68 \%$ on the left side; for women, the positive predictive value of the Baudoin index was $36.6 \%$ on the right side and $38.65 \%$ on the left side.

Fig. 1. Photograph showing the occipital condyles of skull of a female person of 45 years old. Lines indicate the maximum width and length with which the Baudoin index is calculated.

\begin{tabular}{|c|c|c|c|c|c|}
\hline & Sex & $\mathrm{n}$ & Mean & SD & $\mathrm{p}$ \\
\hline \multirow[t]{2}{*}{ Maximum width of the right condyle } & Male & 144 & 12.76 & 1.584 & \multirow{2}{*}{0.211} \\
\hline & Female & 71 & 12.49 & 1.311 & \\
\hline \multirow[t]{2}{*}{ Maximum length of right condyle } & Male & 144 & 23.49 & 2.663 & \multirow{2}{*}{0.000} \\
\hline & Female & 71 & 22.13 & 2.150 & \\
\hline \multirow[t]{2}{*}{ Maximum width of the left condyle } & Male & 144 & 12.86 & 1.527 & \multirow{2}{*}{0.074} \\
\hline & Female & 71 & 12.48 & 1.361 & \\
\hline \multirow[t]{2}{*}{ Maximum length of the left condyle } & Male & 144 & 23.21 & 2.856 & \multirow{2}{*}{0.000} \\
\hline & Female & 71 & 21.72 & 2.295 & \\
\hline
\end{tabular}




\section{DISCUSSION}

We conclude that the Baudoin condylar index has a low yield as a diagnostic test for determining the sex in the skulls studied, despite being a method recommended by various authors (Testut \& Latarjet; Vanrell; Galvão; Da Silva). This situation can be explained by looking at the methods currently in use to test the accuracy of diagnostic tests, they are mainly based on the analysis of differences with statistical significance, which in our study was, in turn, based on the maximum length of the occipital condyles, and by calculating the percentage of success. In this study, the accuracy decreased considerably due to the number of skulls that were found in the range between $50 \%$ and $55 \%$, and therefore diagnosed as indeterminate. From the point of view of accuracy of the test, these indeterminate results must be consideredincorrect for this group of men and women. These results are consistent with the low levels of sensitivity that presented as evidence in the test, in both men and women.

A relevant fact in the positive predictive value of the Baudoin index was that it was unexpectedly high in men, the probability that the skull belonged to a male individual increases when the Baudoin index is less than $50 \%$ on the right side and is $77.6 \%$, and $76.68 \%$ on the left side, indicating that the test is relative, to assist in diagnosis for females, when used with a high sensitivity test for women.

The level of agreement in the diagnosis of sex of the same skull in determining the Baudoin index from the occipital condyle of the left and right sides was high, especially in women $(80.63 \%)$, this suggests that the sample presented low levels of asymmetry in the size of the occipital condyles. We should add that due to endocondral development of ossification of the occipital condyles, external influences on the model of the form are minimal. In this regard, Suazo et al. (2008b) showed that skulls of individuals with severe malnutrition have similar levels of accuracy for the diagnosis of sex, noting characteristics of the occipital bone, than skulls of individuals without this condition, reinforcing the low susceptibility to the change in shape caused by environmental factors. Despite this background, the overall accuracy of the Baudoin method is low $(41.39 \%)$, therefore the real applicability of this index is questionable.

In conclusion, the Baudoin index presented low performance when the diagnostic value was analyzed to determine sex in human skulls, and we recommend caution in its application in forensic anthropology practice, and advocate emphasis on other techniques.

SUAZO G. I.; ZAVANDO M. D.; RUSSO P \& SMITH R. L. Evaluación de la prueba diagnóstica índice condíleo de Baudoin para determinación del sexo. Int. J. Morphol., 28(1):171-174, 2010.

RESUMEN: El presente artículo analiza el rendimiento de la prueba diagnóstica para la determinación del sexo en cráneos humanos, del índice condíleo de Baudoin, para ello se analizaron 215 cráneos, determinándose las dimensiones máximas (largo y ancho) de los cóndilos occipitales derecho e izquierdo. Con estos datos se calculó el índice de Baudoin y se determinó el nivel de concordancia entre los lados derecho e izquierdo, la sensibilidad del método, su exactitud, el valor predictivo positivo para cada sexo. El nivel de acuerdo en el diagnóstico a ambos lados fue de 65,58 \% (mujeres 83,09\%; hombres 63,88\%), estos valores disminuyeron al analizarse sólo los correctamente diagnosticados. La exactitud general fue 41,39\% con una mayor sensibilidad en mujeres (52,1\% lado derecho; y $64,78 \%$ izquierdo). El valor predictivo positivo fue mayor en cráneos de hombres (77,6\% lado derecho; 76,68\% lado izquierdo). Estos resultados cuestionan la utilidad del índice de Baudoin para el diagnóstico del sexo y discuten su aplicabilidad en la práctica forense y antropológica.

PALABRAS CLAVE: Dimorfismo sexual; Determinación del sexo; Cóndilos occipitales; Índice de Baudoin; Índice condíleo.

\section{REFERENCES}

Baudoin, M. Un crâne ancien à troisimème condyl de l’occipital. J. Practiciens, 42:782, 1928.

Da Silva, M. Compendio de Odontología Legal. Rio de Janeiro, Guanabara Koogan, 1997.

Galvão, L. C. C. Identificação do sexo através de medidas cranianas. Tese de mestrado, São Paulo, Piracicaba, 1994.
Galvão, L. C. C. Medicina Legal. São Paulo, Ed. Santos, 2008.

Kalmey, J. K. \& Rathbun, T. A. Sex determination by discriminant function analysis of the petrous portion of the temporal bone. J. Forensic Sci., 41:865-7, 1996.

Kemkes, A. \& Gobel, T. Metric assessment of the "mastoid triangle" for sex determination: a validation study. $J$. Forensic Sci., 51:985-9, 2006. 
SUAZO G. I.; ZAVANDO M. D.; RUSSO P \& SMITH R. L. Evaluation of the Baudoin condylar index diagnostic test for sex determination. Int. J. Morphol., 28(1):171-174, 2010.

Krogman, W. M. \& Iscan, M. Y. The human skeleton in forensic medicine. Springfield, Charles C. Thomas, 1986.

Krogman, W. M. The human skeleton in forensic medicine. Postgrad. Med., 77:A48 72, 1955.

Machado, S. R.; Marques, M. R.; Cardoso, L. M.; Souza, S. B. Galvão, L. C. C. \& Marques, J. A. M. Verificação da aplicabilidade do índice de Baudoin para a determinação do sexo. Disponível em: URL: http:// www.ibep-ba.com.br/publica9.htm, 2000.

Rogers, T. L. Determining the sex of human remains through cranial morphology. J. Forensic Sci., 50:493-500, 2005.

Suazo, G. I. C; Zavando, M. D. A \& Smith, R. L. Sex determination using mastoid process measurements in Brazilian skulls. Int. J. Morphol., 26(4):941-4, 2008a.

Suazo, G. I. C; Zavando, M. D. A \& Smith, R. L. Evaluating accuracy and precision in morphologic traits for sexual dimorphism in malnutrition human skull: a comparative study. Int. J. Morphol., 26(4):876-83, 2008b.

Suazo, G. I. C; Zavando, M. D. A \& Smith, R. L. Sex determination in mandibles in the first year of life by a quantitative approach. Int. J. Morphol., 27(1):113-6, 2009a.

Suazo, G. I. C; Russo, P. P.; Zavando, M. D. A \& Smith, R. L. Sexual dimorphism in the foramen magnum dimensions. Int. J. Morphol., 27(1):21-23, 2009 b.

Suazo, G. I. C; Zavando, M. D. A \& Smith, R. L. Performance Evaluation as a Diagnostic Test for Traditional Methods for Forensic Identification of Sex. Int. J. Morphol., 27(2): 2009c.

Testut, L. \& Latarjet, A. Tratado de anatomía humana. Barcelona, Ed. Salvat, 1974. V. I.

Vanrell, J. P. Odontología Legal \& Antropologia Forense. Rio de Janeiro, Guanabara Koogan, 2002.
Correspondence to:

Prof. Dr. Iván Suazo Galdames

Morfología

Avenida Lircay s/n oficina N¹04

Universidad de Talca

CHILE

Phone: 56-71-201682

Email: isuazo@utalca.cl

Recibido : 30-07-2009

Aceptado: 30-11-2009 